TITLE: Professional development seen as employment capital Author: Margaret Mackay

Submission Journal: $\quad$ Professional Development in Education

Submission type: $\quad$ Research paper

Word count: $\quad 7,212$

Corresponding author: Margaret.Mackay@ port.ac.uk

Correspondence details: University of Portsmouth

The Business School

Portland Street,

Portsmouth PO1 3DE

Hampshire

United Kingdom

Tel: 02392844277

Fax: 02392844037 


\section{Professional development seen as employment capital}

Practitioners need to invest in professional development to enhance credibility, job security and employment prospects. Employer expectations of continuing development as a performance measure link to the notion of career capital; namely that knowledge competence influences job advancement. This study uses an interpretavist approach to explore whether human resource practitioners see professional development as capital. The findings reveal that individuals appreciate the impact of development in confidence, selfefficacy and resilience. This study illustrates the deeper psychological value of continuous learning which diverges from the prevalent career literature assumptions of professional development to increase earnings. The implication for educators is to challenge an impoverished view of professional development limited to career advantage. Professional development can sustain individual growth, optimism and empower individuals to fulfil their potential in contributing to society. In articulating a wider appreciation of ongoing development, educators provide a counterbalance to a restrictive managerial view of professional education.

Keywords: professional development; career capital; social capital; continuous learning; employment

\section{Introduction}

Professional development is regarded as a stock of knowledge, skills and learning for use in work and potential career progression (Harris and Ramos, 2013). This paper explores the connections between capital and continuing professional development (CPD) as an employment resource. Inkson and Arthur's (2001) concept of 'career capital' represents accumulated development and knowledge competence for job progress. Increasingly workplace expectations of professional development as a performance measure signal a view of learning development that supports this notion of capital for career growth (Accenture, 2014). But do practitioners regard their learning development as capital? This study aims to advance the debate about continuing professional development as career advancement by first, providing empirical insights and second, interrogating a dominant managerial view in the literature of learning as a means to an end. Kennedy $(2014$, p689) argues 'the literature on teachers' CPD as a whole is partial in its coverage, is fragmented and is under-theorised'. In attempting a response to this call, this paper brings attention to a managerial discourse of professional development as employment capital. In doing so, there are opportunities within education to expand understandings of ongoing professional development and explore the effects of learning in sustaining practitioner livelihoods. Although rooted in an HR practitioner context, the findings offer insights on professional development applicable to teacher educators of related professional programmes, and more widely those in education. The implication for educators is to encourage appreciation of professional development as more than a means to employment, but also a path of continuing education with access to life enriching opportunities of social and cultural significance.

Initially it must be acknowledged there are clear economic reasons for an instrumental focus on continuing professional development at the individual level, the organisational level, and the societal level. First, at the micro level, individuals need to invest in continuous development to enhance job satisfaction, professionalism, and job security (Volles, 2014). Second, at the organisation level, employers demand talent development through the spread of performance contracts which expect employees to demonstrate proactive self-development (Ellinger, 2004). Third, at the macro level, society needs adult participation in continuous 
learning to improve workers' access to changing labour markets and support their ability to remain in work (OECD, 2001). Continuous development supports employment for longer working lives and helps to improve mobility within the labour market (McNair, 2012). Therefore research that investigates perspectives of professional development as employment capital is of strategic interest to employers, educators and public bodies.

The research is structured around two central questions that explore practitioners' experience of professional development. Specifically the questions examined: the perceived meaning of a development portfolio and to what extent this learning represents capital for career use. In bringing practitioner voices into the discourse of professional learning as career capital, this paper adds new insights on continuous development with a purposive sample of human resource (HR) practitioners. This paper argues that an instrumental view of learning development limits appreciation of deeper skill growth and knowledge capability. Practical implications of this study are that teacher educators need to increase recognition of continuing development as a psychological resource to support extended working lives.

I begin by reviewing the theoretical concept of capital, and examine assumptions of professional learning as an economic exchange in contemporary markets through individual, employer and societal interests. Then I outline the methodological approach, and discuss data findings. Finally, I consider the contributions of this research for professionals, employers and teacher educators in higher education.

\section{Professional development as capital}

The career literature resonates with an implicit economic view of development, which suggests employers offer job advancement in exchange for mastery of specific competencies. In conceptualising professional development as accumulating capital, Inkson and Arthur (2001) use a set of competencies that influence career advancement. Career capital is based on improving competencies in three areas: 'knowing how' the application of relevant skills and knowledge; 'knowing why' the identification of motivation and personal meaning, and 'knowing whom' the access of social contacts and networks (Seibert, Kraimer and Linden, 2001). Kennedy's (2005, p248) broad framework for professional development analysis suggests an 'award-bearing model' of CPD that provides a mark of quality assurance, and thus aligns with the conceptualisation of development as measurable capital. Career success is therefore entwined with continuing development as Arthur, DeFillippi and Jones assert (2001, 99): 'People's past learning experiences are the 'career capital' they invest in their current project activity'. Certainly organisations rely on talent development (Thunnissen, Boselie, and Frutyier, 2013) but whether expanding job-competence will ensure career progress is open to question. Inkson and Arthur (2001) assert the significance of careers claiming: 'careers are what we judge our lives by' (p48). However, this assertion only holds for those who perceive ascending a career ladder of role seniority a measure of success. For others job positions may function as a financial necessity not a core identity. Consequently, interpretations of career capital are subjective as employee ambitions change with age, family life and employment circumstances (Maurer and Chapman, 2013). The notion of professional development as capital is therefore ambiguous: as value is shaped by specific contexts, and determined by the supply and demand of available expertise within sectors. For example, 
engineering and IT skills are in demand globally and this affects the perceived value of knowledge competence (Accenture, 2014). In examining capital in relation to professional development I first consider the rationale for individuals; then discuss employer interests in development; and finally note societal interests in continuous learning.

\section{Individuals as investors in learning}

A decline in stable, long-term career paths has strengthened the rationale for individual development. Continuing development demonstrates up-to-date knowledge and skills as Harris and Ramos (2013, p621) note:

'in order to maintain their currency, individuals are identifying the need to engage in further learning, particularly in situations where they work for a living at the tasks of developing or using knowledge that is changing rapidly.'

So, professional learning can be seen as an investment to protect employment continuity and to enhance job progress (Rothwell, 2005). New work opportunities stimulate learning and Maurer and Chapman's longitudinal research (2013, p463) indicates that 'employees who participate in development activities over time may experience more promotions'. This emphasis on the utility of job-related learning underlines individual accountability (Tams and Arthur 2010), and the depiction of individuals as 'investors' in learning is influenced by corporate interests (Pratt, Rockmann and Kaufmann, 2006). For example, Leitch, McMullan and Harrison (2013) observe: 'In the development of capital, it is still the individual who is central to the theory and who accesses, controls and increases social capital resources' (p351). But Kennedy $(2010,822)$ objects that 'knowledge cannot create value in isolation but can only do so as part of the totality of the living labour power that is subject to valorization within the circuit of capital'. This counters an emphasis on individual autonomy as knowledge creation and innovation may depend on collective social interactions. Therefore assumptions of career capital that place a value on individual contributions may overlook the collaborative interactions of development activity.

External to the individual domain are social networks operating on trust and mutual respect for personal contacts. Social networks expand useful connections, work opportunities and fit the 'knowing whom' dimension of career capital (Seibert et al., 2001). Social capital is an integrated form of career capital that mobilises the support and influence of other people for job progress (Sullivan \& Baruch, 2009). For example, recognition of performance is enhanced through powerful allies and influential mentors. These relationships of trust only develop over time and social capital is a context-dependent process (RSA, 2011). But Fine (2010) contests the theoretical basis of social capital, objecting to a lack of conceptual clarity. This prevalent discourse in the literature of individual investors influences professional development curricula and may constrain scholarly aspirations in framing development by corporate priorities rather than broader educational goals.

\section{Employers interest in capitalising on development}

For employers there are strategic reasons for harnessing employee development, skills and knowledge capability to boost organisational success (OECD, 2001). Talent development can increase business value and Thunnissen et al. propose (2013, 1757): 'Talents are a long term 
corporate asset and should be treated like one'. Yet despite the potential collective gain in organisational productivity, employers hold employees accountable for developing knowledge currency (Maurer and Chapman, 2013). This can be interpreted as absolving employers of the responsibility to support and develop staff. There is an assumption of managerial interest that prevails in viewing development as capital for organisational use. Yet this prominent neoliberal discourse in management spheres overlooks complex business markets where continuing professional development is no guarantee of job security (Work Foundation 2010). Kennedy (2010) points to some inherent contradictions of capitalism: employers demand more skills development while at the same time deskilling, restructuring and out-sourcing jobs in response to global competition. Research by the Resolution Foundation $(2014$, p3) tracks the rise of self-employment; individuals 'forced to go it alone' as businesses deploy tactical mergers and zero hour contracts to minimise employer liabilities. In a Canadian context, Cruikshank (2008, p55) remarks: 'the rhetoric talks about knowledge jobs, workers talk about flipping burgers and call centers'. In this environment, the benefits of professional learning are reduced to a defence strategy of employability. Moreover, access to workplace development opportunities is often skewed; for example, the Work Foundation (2010) reports professionals and managers receive more training than those in unskilled jobs but in the UK public and private sector employers decreased training expenditure by $5 \%$ in 2007-2009. Few employers consider employee development training as equivalent to an investment in physical capital (Volles, 2014). Further, Coffield (1999)

argues that continuous learning operates as a social control affording capital to those who have greater access to education, secure jobs and training opportunities. For example, HR practitioners are encouraged to demonstrate a learning portfolio to: 'showcase their credentials...ensure they stand out in their career development [and] are respected and valued by employers' (www.cipd.co.uk). This emphasis on credentials narrows recognition of informal ongoing development, and how teamwork interdependency can lead to collective skill growth that enhances organisational value. A utilitarian discourse of learning capital weakens awareness of the longer-term value of professional development and education in its widest sense.

\section{Societal interest in continuing development}

Societal interest in continuing development centres on practitioners' adaptability in the job market (Boud and Hager, 2012). Numerous studies show that learning development positively affects job competence, job prospects and additionally expands useful skills and knowledge for everyday life (e.g. the European Commission 2005; RSA 2011). Increasing longevity globally and rising European retirement ages accentuate the need to extend working lives beyond traditional stages to meet skill gaps (McNair, 2012). Accordingly, research initiatives that encourage individuals to appreciate continuous development as a lifelong attitude to learning are of strategic interest to society and the role of educators in supporting practitioners.

Critics argue that industry calls for more public financing of skills development seek a government response to satisfy employers competence needs (Resolution Foundation, 2014). Cruikshank (2008, p235) asserts 'a knowledge-base economy is far from fully realised when 
growing numbers cannot use their qualifications in meaningful jobs'. Moreover, the promises of continuing development that addresses societal issues can appear idealistic. When interrogated the implicit promise of career capital reveals tensions in the expectation that practitioners who 'bank their development' will remain competitive (CIPD 2012). For example, shifting labour markets threaten job security and technological changes deskill jobs which erode the power of learning development to affect career prospects. In educating practitioners, and extending their right to learn, there is a need to realise the wider impact of professional development to everyday practice and the importance of social learning in supportive communities (Wenger and Snyder, 2000).

\section{Model of career agency in professional development}

The career literature emphasises individual responsibility for professional development even though social interactions and organisational context may be more significant in facilitating job opportunities. Learning often relies on a supportive context for the individual to effectively develop relevant working knowledge (Kennedy, 2005).

One example reflecting this emphasis on individual agency is Hirschi's framework (2012) which synthesises much of the literature of self-directed career management. Drawing on this model I examine what insights this framework provides on career capital in relation to continuing professional development. For Hirschi $(2012,378)$ career resources are not static but require constant attention; he describes these resources as:

'assets that change in a dynamic process of mutual reinforcement over time [...] the existence of resources in one area promotes the development of resources in other areas.'

This insight into the fluidity of professional knowledge, skills and behaviours implies a difficulty in measuring the value of development. Hirschi's model (2012) positions the individual practitioner as central to integrating career management skills depicted as four resource areas: identity, human capital, psychological and social resources. 


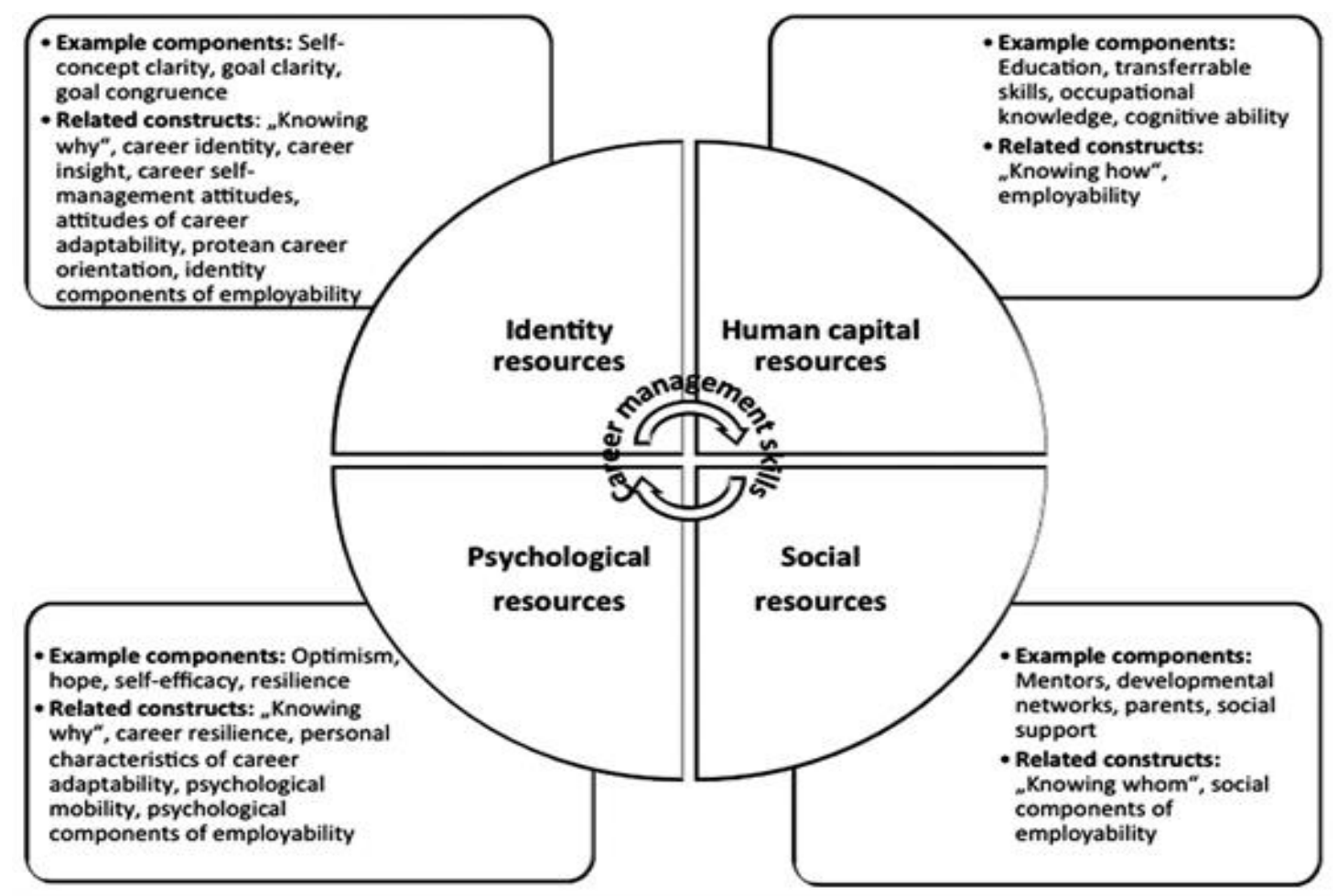

Figure 1 Adapted from Hirschi 2012 p376

For educational development Hirschi's guidance resonates with HR practitioner frameworks which structure learning around critical reflection, accumulating competence and deliberate development to enhance career management. One set of resources strengthen another in expanding knowledge and skill currency. For example, a greater social capital of allies and mentors supports mastery of professional know-how (Tams and Arthur, 2010). This echoes Harris and Ramos' claim (2013) that the more an individual is aware of their abilities, work goals and values, the more career advantage in practice.

But for any practitioner this model presents a daunting agenda of professional development. A self-managed career assumes continuous improvement as normative behaviour. Consequently, a lack of career advancement may be judged as a failure of individual effort. Cooper's research (2010) reveals individual frustration, and debilitating stress of employees facing such imposed career aspirations. An emphasis on self-directed development neglects the rise in temporary low-skilled contracts that reduce employee control and exacerbate social divisions and inequality (Work Foundation 2010). Boud and Hager (2012) contend that much workplace learning consists of informal collaboration; for example, peer interactions, coaching conversations, and unexpected social opportunities. Work contacts and social connections may acquire more importance than educational credentials in practice. Social capital may accelerate job progress more rapidly than knowledge development in a specific company context.

To summarise, a view of learning as capital is open to critique. To perceive the individual as able to control professional development as a lever to job advancement overlooks the environment and organizational context. An assumption that individual agency secures job advantage is constrained by employer interests and the labour market. Power 
relationships in employment situations may hamper practitioner development and job prospects (Kennedy, 2010). This study examines a specific higher education context of professional development with a purposive sample of HR practitioners' and explores to what extent a professional qualification signals capital for career progress.

\section{Phenomenological Methodology}

Appreciating practitioners' everyday learning experiences can illuminate the discourse of professional development (Leitch et al., 2013). HR practitioners are spotlighted because they are regarded as guardians of professional learning with commitment to development enshrined in their professional standards (CIPD Code of Professional Conduct, 2012). Eraut (2000) observes that practitioners are immersed in their professional work context and learning is therefore intertwined with their situation. A hermeneutic phenomenological research approach aligns with the situated nature of professional development. Further, individual practitioners adapt to emerging situations and therefore examining this subjective perspective is of interest in the context of professional education.

The context of professional learning intertwined with workplace practice, allows for a qualitative research approach to investigate what Cunliffe (2004) describes as rich insights and thick descriptions that individuals hold of their own development progress. An interpretavist method focuses on the interconnections of development and learning context reflected in learning portfolios (Boud and Hager, 2012); everyday practice that shapes individual sense-making of professional development experiences (Bryman and Bell, 2007; Saunders, Lewis and Thornhill, 2012). Here the portfolio is taken as a formal collection of written logs that capture learning and reflect on workplace development. Portfolios capture learning development and reflect on the meaning of experience. Billett (2008) supports the use of self-reported accounts in analysis of the continuous process of learning through work experiences. Billett states: 'Personal constructions reflect the past, the agency and the intentionality of individuals can also be directed toward the future' $(2008,52)$.

\section{Method}

The first stage of the study involved a close look at 30\% of practitioners' personal statements, selected randomly in date order of receipt from a total 84 applications $(n=25)$. This review of statements in support of a postgraduate diploma in HR management over two consecutive academic years 2012-2014, indicated strong alignment of professional qualification with career expectations. This secondary data confirmed applicants' perception of professional education as a career credential. Then research participants were invited from three separate cohorts across two collaborative UK university-based campuses of $53 \mathrm{HR}$ practitioners enrolled on a postgraduate study programme. The data collection was in two stages: first, practitioners individually recorded a written record as an element of a skills development portfolio reflecting on learning. The use of development portfolios supports the validation of systematic, self-directed learning to update professional knowledge and skills. Tracking development is regarded as a duty of professional service that assures the public of legitimised expertise and provides evidence of progress (Boud and Hager, 2012). Friedman and Phillips (2004) assert that reflective practice has come to be considered a key element of 
professionalism in extending learner agility to cope with unexpected changes, but how this reflection informs self-awareness, knowledge development and social learning is less explicit.

The second stage of data collection involved a sub-sample group of 27 practitioners in a series of focus groups to collectively share perceptions of development experiences. These focus groups involved 4-5 participants in each discussion group who met towards the end of the development programme. Guiding research questions facilitated discussion: a) how do you see your learning development? and b) in what way are these learning experiences useful for current job activity and future career? The seven focus groups were held on three separate days across the two campus sites with participants' informed consent. Basing discussion around the guiding questions, participants were asked to note and collate a 'wall' display of observations, thoughts and impressions of professional development. This visual mosaic provided a social opportunity to share experiences as a peer community of practice (Wenger and Synder, 2000). Group discussions triggered further recollections of learning experiences, and individuals made connections between apparent fragments of knowledge and learning of relevance for the future.

Preliminary data analysis assigned open-coding to the participant data which involved 87 initial codes and followed Weston et al.,'s (2001) method of coding qualitative findings. These codes were then grouped into 8 sub-categories: knowledge as HR practitioner; technical skill development; awareness of social context; gaining respect of others; future prospects in work; seeing oneself differently; self-confidence; being a professional. From these overlapping subcategories three principal categories were identified and extracted as 'practitioner competence', 'social context' and 'professional self-worth'. Table 1 shows the frequency of coding and main categories of responses.

\begin{tabular}{|l|c|c|c|}
\hline Main Categories & $\begin{array}{c}\text { Practitioner } \\
\text { competence }\end{array}$ & Social context & Self-worth \\
\hline Reflective Journals & Frequency $=37$ & Frequency $=10$ & Frequency $=29$ \\
Total 53 & $70 \%$ & $19 \%$ & $55 \%$ \\
\hline Focus Groups & Frequency $=13$ & Frequency $=4$ & Frequency $=14$ \\
Total 27 & $48 \%$ & $14 \%$ & $52 \%$ \\
\hline Total 80 & $50 /$ & $14 /$ & $43 /$ \\
Percentage & $\mathbf{6 3 \%}$ & $\mathbf{1 8 \%}$ & $\mathbf{5 4 \%}$ \\
\hline
\end{tabular}

Table 1 Main categories of responses

In an initial analysis these three data categories were compared against Hirschi's model that implies resources in all four areas are of equal importance. This helped to tease out further the emphasis respondents placed on professional development.

The study limitations are acknowledged in the nature of self-reports of developmental learning (Bryman and Bell, 2007). A learning portfolio is to an extent a creative construction of narrative interest for each individual in a specific context. A retrospective view of learning can project an embellished view of development that responds to professional body requirements (Alvesson, 2010). Learning accounts are also influenced 
by the educational context and the social group perceptions of valuable development. Nonetheless, this exploratory study does offer insights into working practitioners' views as adult learners engaged in professional development and interpretations of the theoretical construct of learning as capital. The data findings are discussed next.

\section{Gains from a stock take of development}

To present findings I draw on the concept of career capital; that knowledge and skill resources influence career advancement (Sullivan \& Baruch, 2009). Bringing attention to this instrumental view in the literature of professional learning opens up practitioner understandings of ongoing development. The data presentation of three main categories is followed by a discussion of critical issues emerging.

The dominant themes from practitioner responses in individual portfolio reflections and focus groups were the significance of developing clarity about the human resources role, or occupational identity, and the appreciation of developing confidence in knowledge competence. Surprisingly, although practitioners had initially emphasised the impact of acquiring an advanced level qualification this received limited remark. One interpretation is that this professional accreditation is taken for granted. The exercise of taking stock of development through a learning portfolio strengthens awareness of development progress (Mackay \& Tymon, 2013). The table below sets out qualitative examples of practitioner reflection on professional development:

\begin{tabular}{c|l}
\hline Main category & \multicolumn{1}{c}{ Illustrative response } \\
\hline $\begin{array}{c}\text { Knowledge competence } \\
\begin{array}{c}\text { Understanding role, occupational identity } \\
\text { and goal clarity }\end{array}\end{array}$ & $\begin{array}{l}\text { The course has given me an understanding of what is needed for a role } \\
\text { in human resources and the need for my continued professional } \\
\text { development. I had previously become lost with direction in life. I had } \\
\text { allowed my skills and abilities to suffer but starting the course has } \\
\text { enabled me to find my direction for my career. [Manager] }\end{array}$ \\
\hline $\begin{array}{c}\text { Social network } \\
\text { and support of others }\end{array}$ & $\begin{array}{l}\text { I have learnt that the networking and social aspects of these Branch } \\
\text { events, is a potential source of future employment. Upon reflection } \\
\text { my aim is to mirror the other professionals attending the events, so } \\
\text { that I portray the right image with the way I dress, the way I conduct } \\
\text { myself. This way I hope to be more approachable and hope potential } \\
\text { employers will see me as a future employee. [HR Business Partner] }\end{array}$ \\
\hline Credibility, and confidence & $\begin{array}{l}\text { My confidence in my own ability has grown dramatically, as has my } \\
\text { professional credibility in taking this course. As a result of my } \\
\text { increased confidence I am involving myself in casework situations } \\
\text { that I would not have done before... [HR Advisor] }\end{array}$ \\
\hline
\end{tabular}

Table ii. Practitioner identification of developing capabilities

\section{Development of knowledge competence}

The sample shared an educational goal of attaining professional qualification in building job competence and skills. The development of knowing how concerned practitioners, to be current and knowledgeable in the workplace. From the data it is clear that professional 
credibility entwines with perceptions of occupational knowledge for the future. Practitioners perceived commitment to career development and professional accreditation as an external signal of credibility.

'I realised that having been a line manager I had learnt many skills that were transferable. I chose this qualification to gain professional credibility for my career'.

Practitioners see professional development opens up self-awareness that can lead to insights:

I think the biggest change is a mindset. So, getting a better understanding of myself has increased my self-confidence and made me realise I do have a range of experience and knowledge already.

Recording development activities can increase clarity of job goals and an expansion of occupational identity supports a better appreciation of skill development (Alvesson 2010). The data exemplify individuals growing awareness of the HR role through reflective learning, and of their job position in the organisation. Wider education as a practitioner shapes an identity as a professional; what Khapova and Arthur (2011) term 'knowing why' purpose of everyday activities. The development of identity resources was seen as important with $63 \%$ of responses identifying goal clarity and development direction as valuable. In the reflective journals $70 \%$ of practitioners focused on the development of role understanding and purpose. The process of reflection, a stepping back, afforded by an educational space allows practitioners to consider what is significant in developmental learning. An educational context legitimises time for reflection that supports insight on progress as a practitioner.

\section{Development of social network}

Fewer respondents' appreciate the value of social networks to boost their professional development; less than a fifth $18 \%$ of participants mentioned social resources as a source of guidance, support and opportunity in extending learning. This contrasts markedly with more than two-thirds, $63 \%$ of practitioners, who value identity resources. Comments on social influences held up the professional community as a benchmark of standards. The community of practice represents an aspiration for practitioners who seek to belong and acquire social status as a respected professional. For example, one practitioner sets out a plan to network with other specialists:

I have managed to develop valuable relationships with my colleagues and tutors from all walks of life. I appreciate the importance of working with others in sharing our knowledge, skills and experience. I need to bring my HR knowledge up to the right level and build a network of relations with HR professionals.

This sensitivity to the need for work-related social connections resonates with social capital dimensions (Seibert et al., 2001). For example, 'people with a clearer sense of who they are and what they want, knowing why, more easily build social networks, knowing whom, and acquire relevant knowledge' (Hirschi 2012, 377). In the focus groups some 19\% (5/27) voiced concerns about their working know how in the social domain:

We're a small community here; any doubt about your working knowledge can damage your credibility. It sticks to you.

But the majority of practitioners, $70 \%$ of journal mentions, focused on self-directed development as a priority. This indicates practitioner acceptance of learning responsibility, echoing the career literature agency (Ellinger 2004) and business influence that holds 
individuals accountable for professional development. A concentration on individual accountability overlooks the support of others in development and the fortifying role of social networks for learning.

\section{Development of self-worth}

Taking stock of development boosts analysis of work behaviour; this aided a growing sense of self-worth that increases personal confidence and belief in capability.

I am gradually starting to think less critically about myself and start to recognise where my strengths are, areas of success and just what I have achieved so far. My growing confidence has surprised me... and I now approach my current job more positively.

More than half, $52 \%$ of the focus groups, and 55\% of journals, affirmed that growing confidence in working knowledge contributes to short-term job performance needs. But this did not necessarily represent capital for use in the workplace as competing organisational pressures were mentioned. However, 22 respondents, $42 \%$ of journals (22/53), observed that the exercise of looking back on development renewed a sense of achievement and invigorated optimism. For example:

it gives me the courage to feel I can find work that I enjoy, even if it takes me years - it's in my reach and everyday there are possibilities.

This resonates with the literature that encourages workers to hone their skills for transitions and work changes (Sullivan and Baruch, 2009). The assumption in career capital of development leading to career movement was doubted by one focus group observation on the difficulties of employment:

I do invest in my development. But when is personal development related to my professional achievements? I know I have changed a lot and adjusted how I look at things now but I don't think this will make a difference to the job that I can get. I lack experience as a team leader, or manager and this will hold me back. There is no guarantee around career opportunities.

Learning resilience was seen as critical in adapting to changing business conditions (Leitch et al., 2013). Practitioners were more aware of the need to cultivate skills that sustain a robust attitude to work challenges and strengthen a belief in professional self-efficacy. For example, one respondent reflected:

I questioned my motivation in taking this course and realised it's not the promise of more money. It's the opportunity this gives me in working with people, supporting the organisation, earning respect and making a difference for the better. It's about my self-esteem.

This practitioner notes the intrinsic benefits of professional learning in strengthening their capability to make a contribution to others, and thereby enhance self-esteem.

\section{Critical issues emerging}

The data offer contextualised understandings of professional development for practitioners studying in higher education to acquire advanced level qualification. The context of professional accreditation implies a participant sense of instrumentality in development. Interestingly, participants adopt longer-term views of development and value personal growth and self-efficacy as important capital. This differs from the literature that assumes learning development is predominantly utilitarian for career advantage (Inkson and Arthur, 2001). 
Several practitioners in journal reflections (11/53) $21 \%$ were ambivalent as to whether professional development increased immediate job progress, but took confidence in the longer-term effects of building self-awareness.

\section{Individual development of self-worth}

Practitioners regarded self-efficacy as significant in development; a psychological aid that better equips individuals with an armoury of skills. The notion of capital implies a tangible asset but the majority of respondents saw learning as a perpetually evolving process that encourages a sense of self-worth. These psychological resources sustain and affirm a sense of developmental progress. For example:

As a graduate trainee my current role might sometimes be a bit de-motivating because of all the administrative work and less challenging tasks without much responsibility. This [portfolio] made me realise that it is still an important phase in my career as I have the opportunity to build a sound basis for further development. In the future, I see myself as a confident and influential HR professional in a truly strategic role valued by the business.

This observation illustrates a practitioner reflecting how a menial role can enlarge coping skills for future employment. Of note here is the dynamic nature of development that builds transferable skills. As working lives elongate, then learning development can support individual tenacity to continue working (Volles, 2014). This characteristic of staying power equips individuals for diverse employment conditions and to support the long-term span of career progression. This attests to the iterative affects of reflexive learning (Mackay and Tymon, 2013) and supports ongoing interest in learning for life. A retrospective stock take of development renews individual confidence in professional growth and sustains motivation to carry on learning.

\section{Role of collective learning}

The economic judgement of 'worth' focuses on individual expertise and capital through professional learning but this neglects the collective endeavour of most organisations. A restricted focus on the individual disregards the social learning implicit in collaborative exercises, team working and productive partnerships. A narrow conception of development overlooks the cultural enrichment of learning from supportive networks, cultivated in practice contexts and made explicit in professional communities (Pratt et al., 2006). The role of learning communities needs greater appreciation in continuing development (Kennedy, 2014) as a powerful source of collective professional development that supports social well-being and the creation of new knowledge. An educational programme allows space to ruminate in learning groups on diverse work experiences and tease out understanding through reflective thinking. These shared realisations further stimulate group development momentum and renew collective commitment to learning.

\section{Employment prospects}

Practitioners did not anticipate immediate career progress as a reciprocal outcome of professional development. This differs from the career literature that frames development as capital; an instrumental means to job advancement and higher earnings. The findings reveal practitioners are pragmatic in considerations of the multiple factors that affect employment 
progress. The literature view of development ensuring job advancement (Tams and Arthur, 2010) is at odds with individuals' employment experiences. A cautionary perspective was notable in $21 \%$, more than a fifth, of respondents as to whether development improved employment prospects. Consequently, there is a need within schools and higher education to recognise tensions in the promotion of professional development as a source of job leverage. Volles (2014) notes an increasing emphasis on agency in skills development can absolve private companies of the need to invest in employee training; debate about skills gaps and public funding of development education may disguise a jobs crisis that erodes employee power. The prominent managerialist view of career capital attracts criticism; namely, that it imposes accountability for development on employees, neglects uneven access to organisational support for development, and implies individual autonomy is inherent in any employment relationship (see e.g., Coffield 1999). Specific practitioner accounts undermine assumptions of career advance in a merciless global market. For educators there is a need to challenge managerial language that obscures a wider understanding of the positive capabilities that stem from learning development.

\section{Towards a wider view of development capital}

To return to the research question of whether individuals see professional development as a product for use in employment markets, practitioners had a broader view of learning development that enables new ways of seeing work, adapting and building a career. Stiglitz (1999) speaks to the importance of knowledge development increasing our capacity to live in society and contribute to the collective. Investment in professional development matters for the support and enrichment of practitioner growth in self-efficacy and capability. Practitioners viewed learning and continuous development as a critical resource to sustain employment and the motivation to carry on learning. Given the need for higher education to foster a culture that encourages curiosity, challenges existing ideas and generates new ones (Delors 2013); educators can apply this purpose to advancing a broader theoretical view of professional development. Instead of a constricted view of learning as 'career capital', a transaction for employment use, practitioners recognise the intrinsic value and psychological importance of continuous development.

\section{Conclusion}

This study set out to explore human resource practitioners' understandings of professional development as a form of capital for job progress. Although rooted in an HR practitioner context, the findings offer insights on continuing professional development applicable to teacher educators of related professional programmes, and more widely those in education. Educators need to encourage a broad view of CPD; of learning for individual growth and enlightenment, and in doing so, provide a counterbalance to a prevalent discourse that constrains learning to employment use.

An organisation that fosters a learning culture is equipped with competitive advantages in adverse environments. Thus for employers there is strategic interest in harnessing individual development with collective skills value to the organisation; regarding staff as long term corporate assets (Thunissen et al., 2013). For society ongoing learning 
supports working lives and accords with government strategies to reduce the state burden, sustain earnings and job continuity (OECD, 2001; McNair, 2012). Accordingly, professional development can support an intrinsically enriching process of continuity through longer working lives.

This article contributes to debates in education about the need to question a discourse of learning development as exclusively economic capital. These specific findings of HR practitioners have resonance for educationalists in revealing how professional learning supports practitioners' growth in capability and self-efficacy of benefit to the individual, organisation and society. Educators need to resist a narrow view of professional development as private advantage, and articulate the longer-term effects of nurturing capacities for collective practice and greater self-knowledge to contribute to societal interests. Although professional accreditation is a 'gold-standard' credential; practitioners were pragmatic in career expectations. Practitioners see learning as building layers of professional confidence and competence and recognise learning beyond instrumental advancement. Continuing development bolsters professional efficacy, self-awareness and affirms hope in future prospects. The psychological benefits of learning development enhance resilience and sustain motivation to carry on acquiring depth in professional knowledge.

Within higher education an enlarged perspective of continuous learning as a positive psychological construct complements a discourse of employability, and informs better understandings of practitioner development. Future avenues for research can extend empirical data of professional development as psychological and identity resources. Rather than deny an economic perspective, educators can articulate a broader appreciation of development that offers intrinsic value in supporting practitioners' work life and growth. This study attempts to respond to Kennedy's call (2014) to extend the theoretical understandings of professional development, and contributes an interpretation of professional learning as intrinsic capital; a capital of enrichment in social, cultural and educational development. Continuing development is in many professions, and particularly in education, more than a market imperative to adapt to managerial needs. The implication for educators is to elevate the longterm value of professional development that enhances well-being, supports empowerment and individuals' ability to contribute to society.

\section{References}

Accenture March 2014 'Career Capital 2014 Global Research Results'. Accessed online www.accenture.com/IWD2014

Alvesson, M. (2010). 'Self-doubters, strugglers, storytellers, surfers and others: Images of self-identities in organization studies' Human Relations, 63 (2) 193-216.

Arthur, M. DeFillippi, R. and Jones, C. (2001) Project-Based Learning as the Interplay of Career and Company Non-Financial Capital, Management Learning, 32 (1) 99-117.

Billett, S. (2008). Learning throughout working life: a relational interdependence between personal and social agency, British Journal of Educational Studies, 56 (1) 39-58. 
Boud, D., \& Hager, P. (2012). Re-thinking continuing professional development through changing metaphors and location in professional practices, Studies in Continuing Education 34 (1) 17-30.

Bryman, A. \& Bell, E. (2007). Business Research Methods, (2 ${ }^{\text {nd }}$ ed.). Oxford University Press.

Chartered Institute of Personnel Development [CIPD] 2012 Code of Professional Conduct www.cipd.co.uk

Coffield, F. (1999). Breaking the Consensus: Lifelong learning as social control, British Educational Research Journal, 25 (4) 479-499.

Cooper, C. (2010) 'Mental capital and wellbeing' Stress and Health, 26 (1) 1-2.

Cruikshank, J. (2008). Lifelong Learning and the New Economy in The Future of Lifelong Learning and Work - Critical Perspectives, (Eds Livingstone D.W, Mirchandani, and Sawchuk, P.)

Cunliffe, A. (2004). On Becoming a Critically Reflective Practitioner. Journal of Management Education, 28 (4), 407-426.

Delors, J. (2013). "The Treasure within: Learning to Know, Learning to Do, Learning to Live Together and Learning to Be. What is the value of that Treasure 15 years after its publication?" International Review of Education, 10.1007 (1) 1-12.

Ellinger, A. (2004) The Concept of Self-Directed Learning and Its Implications for Human Resource Development. Advances in Developing Human Resources, 6 (2) 158-177.

Eraut, M. (2000). 'Non-formal learning and tacit knowledge in professional work'. British Journal of Educational Psychology, 70 (1), 113-136.

European Commission (2005a) Communication from the Commission on the Social Agenda, European Commission, Brussels.

Fine, B. (2010). Theories of Social Capital: Researchers Behaving Badly, London: Pluto Press.

Friedman, A. and M. Phillips. (2004). Continuing professional development: Developing a vision, Journal of Education and Work 17 (3) 361-376.

Harris, R. and Ramos, C. (2013) Building career capital through further study in Australia and Singapore, International Journal of Lifelong Education, 32 (5) 620-638.

Hirschi, A. (2012) The career resources model: an integrative framework for career counselors, British Journal of Guidance and Counselling, 40 (4) 369-383 doi: 10.1080/03069885.2012.700506

Inkson, K. \& Arthur, M. (2001). 'How to be a successful Career Capitalist'. Organizational Dynamics, 30 (1), 48-61.

Kennedy, A. (2005). Models of Continuing Professional Development: a framework for analysis, Journal of In-Service Education, 31 (2), 235-250.

Kennedy, A. (2014). Understanding continuing professional development: the need for theory to impact on policy and practice, Professional Development in Education, 40 (5), 688-697.

Kennedy, P. (2010). 'The Knowledge Economy and Labour Power in Late Capitalism', Critical Sociology, 36 (6) 821-837.

Leitch, C., McMullan, C. and Harrison, R. (2013) The Development of Entrepreneurial Leadership: The role of Human, Social and Institutional Capital, British Journal of Management, 24, 347-366.

Mackay M. and Tymon, A. (2013). Working with uncertainty in teaching critical reflection, Teaching in Higher Education, 18 (6):643-655. doi:10.1080/13562517.2013.774355

Maurer, T. and Chapman, E. (2013) Ten years of career success in relation to individual and situational variables from the employee development literature, Journal of Vocational Behaviour, 83, 450-465.

McNair, S. (2012). Older People's Learning in 2012: A survey. National Institute of Adult Continuing Education, London. 
Mulvey, R. (2013). How to be a good professional: existentialist continuing professional development (CPD), British Journal of Guidance and Counselling 41, (3) 267-276.

OECD Organisation for Economic Co-operation and Development (2001) The Well-being of Nations: the role of human and social capital, OECD, Paris.

Pratt M., Rockmann K. \& Kaufmann J. (2006). 'Constructing professional identity: The role of work and identity learning cycles in the customization of identity among medical residents.' Academy of Management Journal, 49, 235-262.

Rothwell, A. (2005). How HR professionals rate 'continuing professional development'. Human Resource Management Journal, 15 (3), 18-32.

RSA The Royal Society of Arts July (2011) Norris E., 'Not Enough Capital: Exploring Education and Employment Progression in Further Education', Accessed online http://www.thersa.org

Saunders, M., Lewis, P. and Thornhill, A. (2012). Research methods for business students, $6^{\text {th }}$ ed. Harlow: Financial Times Prentice Hall.

Seibert, S., Kraimer, M. and Linden, R. (2001), 'A Social Capital Theory of Career Success', Academy of Management Journal, 44, 219-237.

Stiglitz, J. (1999). Knowledge as a Global Public Good. Global Public Goods: International Cooperation in the $21^{\text {st }}$ Century. The United Nations Development Programme. New York: Oxford University Press.

Sullivan, S. and Baruch, Y. (2009) Advances in Career Theory and Research: A Critical Review and Agenda for Future Exploration, Journal of Management, 35:1542.

Tams, S. and Arthur, M. (2010) New directions for boundaryless careers: Agency and interdependence in a changing world. Journal of Organizational Behaviour, 31, (5) 629-646.

The Resolution Foundation (2014). Just the job - or a working compromise? The changing nature of self-employment in the UK. May 2014 Conor D'Arcy \& Laura Gardiner. Accessed online http://www.resolutionfoundation.org

The Work Foundation (2010) Employability and Skills: Redefining the Debate. Accessed online www.theworkfoundation.com/

Thunnissen, M., Boselie, P. and Frutyier, B. (2013) A review of talent management: 'infancy or adolescence?' The International Journal of Human Resource Management, 24:9, 1744-1761.

Volles, N. (2014) Lifelong learning in the EU: changing conceptualizations, actors and policies, Studies in Higher Education, DOI: 10.1080/03075079.2014.927852

Wenger, E. \& Snyder, W. (2000). 'Communities of Practice: The Organizational Frontier', Harvard Business Review, January-February.

Weston, C., T. Gandell, J. Beauchamp, L. McAlpine, C. Wiseman and C. Beauchamp. (2001). Analyzing interview data: The development and evolution of a coding system. Qualitative Sociology 24, (3) 381400. 